\title{
Performance Evaluation On Structural Behaviour Of Sisal Fibre Reinforced Concrete
}

\author{
Dr. G.Dineshkumar $^{1^{*} \quad \text { Dr. R.Bharathimurugan }}{ }^{2}$ \\ ${ }^{1,2}$ Associate Professor \\ Department of Civil Engineering, Vaagdevi College of Engineering, Warangal, Telangana State, India. \\ Corresponding Author email id: gdkcivil@gmail.com
}

\begin{abstract}
All over the world, construction industries looking forward for the green materials to meet the structural integrity and sustainability in terms of arresting micro cracks in the concrete and also for a secondary reinforcement materials for addition in the concrete. Internal micro cracks in the concrete will reduce the longetivity of the structure and also it results in structural failure. The use of fibres in the concrete is currently used as a secondary reinforcement for strengthening the reinforced concrete members. To make the concrete as a sustainable material and to improve structural integrity in this research Sisal Fibre was used as a secondary reinforcement. Natural fiber such as sisal fibre, appears as an one of the good alternative since they are available in fibrous form and can be extracted from plant leaves at very low cost. In this work, effect of sisal fiber on the strength of concrete for M 25 grade has been studied by varying the percentage of fibers in concrete. Fiber content were varied by $0.05 \%, 0.10 \%, 0.15 \%, 0.20 \%, 0.25 \%, 0.30 \%, 0.35 \%$ and $0.40 \%$ by volume of concrete. Cubes, Cylinder and Prism were cast to evaluate the Strength Characteristics and to optimize dosage level of fibre in concrete. The reinforced concrete beam was cast by optimum dosage level of fibre to evaluate structural behavior of concrete such as Load deflection, Ductility factor and Stiffness. The result proven, there is significant improvement in structural behavior of Sisal Fibre added Reinforced Concrete when compared to control concrete.
\end{abstract}

Keywords: Sustainability, Fibre reinforced concrete, Sisal fibre, Strength, Ductility, Stiffness

\section{Introduction}

Concrete is weak in tension, so it act as a brittle material. The concept of using fibre to improve the characteristics of construction materials is practiced from olden days. The quality of concrete was evaluated by its mechanical properties and with its ability to resist deterioration. The strength of the concrete is most important characteristics, which it has well-built relationship with quality. The stress-strain behaviour of concrete mainly depends on the properties of the material with which the concrete is cast and by loading parameters.

\subsection{Fibre Reinforced Concrete}

Fibre Reinforced Concrete (FRC) is concrete composites containing fibrous material which its enhance structural reliability. Fibre include steel fibre, glass fibre, synthetic based fibre and natural based fibre. The use of various fibre which lead to varies the properties of the concrete. The characteristics of fibre reinforced concrete changes fibre materials, geometries, distribution, orientation, and densities.

Fibers control cracking due to plastic shrinkage and drying shrinkage. Fibres presence in the concrete will reduce the permeability of concrete and thus reduce bleeding of water. In addition fibres addition in concrete produce greater impact, abrasion, and shatter resistance in concrete.

The fiber modulus of elasticity is higher than the matrix (concrete or mortar binder), they help to carry the load by increasing the tensile strength of the material. The aspect ratio increases in the fiber usually segments the flexural strength and toughness of the concrete of mortar matrix. However, fibres used too long in matrix it tend to ball effect in the mix and it lead to workability problems.

\subsection{Sisal Fibre}

Sisal fibre is extracted from the leaves of the sisal plant. It is usually attained by machine decortications during which the leaf is crushed between rollers then mechanically scraped. The fibre is then tends to washed and dried by mechanical or natural means. The dried fibre represents only $4 \%$ of the entire weight of the leaf. Dry Fibre are subjected to machine combed and sorted into various grades, largely on the idea of the previous in-field separation of leaves into size groups. 


\section{Materials used}

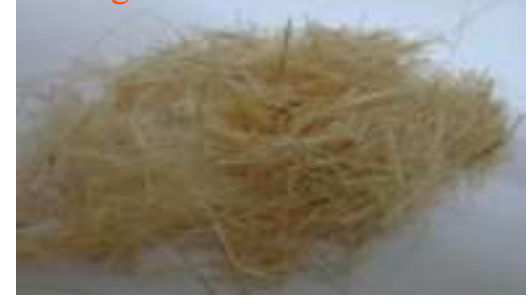

Figure 1 Sisal Fibre

\subsection{Cement}

Ordinary Portland Cement of 53 grade conforming to IS 12269-1987 was used. The physical properties of cement used shown in Table 1

Table 1 Physical Properties of Cement

\begin{tabular}{|c|c|}
\hline Properties & Tested value \\
\hline Standard consistency test & $31 \%$ \\
\hline Initial setting time & $38 \mathrm{~min}$ \\
\hline Final setting time & $276 \mathrm{~min}$ \\
\hline Fineness test & $6 \%$ \\
\hline Specific gravity & 3.11 \\
\hline
\end{tabular}

\subsection{Fine Aggregate}

River sand was as fine aggregate in the study. It was properly graded to give the minimum voids ratio and shall be free from deleterious materials like clay, silt content and chloride contamination. The properties of fine aggregate given in Table 2

Table2 Properties of fine aggregate

\begin{tabular}{|c|c|c|}
\hline $\begin{array}{c}\text { Test for Fine } \\
\text { Aggregate }\end{array}$ & Relevant Code & Result \\
\hline $\begin{array}{c}\text { Specific } \\
\text { gravity }\end{array}$ & IS:2386 -1963 (Part I) & 2.65 \\
\hline Bulk density & IS:2386 -1963 (PartIII) & $1721.32 \mathrm{~kg} / \mathrm{m}^{3}$ \\
\hline $\begin{array}{c}\text { Fineness } \\
\text { Modulus }\end{array}$ & IS:383-1970 & 2.39 \\
\hline
\end{tabular}

\subsection{Coarse Aggregate}

The granite stone is used as coarse aggregate with a nominal size of $20 \mathrm{~mm}$ is conformed to IS $383-1970$. The specific gravity of coarse aggregate is 2.77 .

\subsection{Water}

Portable water is generally considered satisfactory. In the present investigation, water available in laboratory conforming to the requirements of IS: $456-2000$ is used for both mixing and curing purposes.

\subsection{Sisal fibre}

The sisal fibre was obtained from local sources. The fibre was extracted from the leaf of the plant Agave-Sisilian which is available in plenty in the Southern part of India. Sisal fibre which is purchased from Tokyo Fibre, Coimbatore is used for this study. The properties of fibres is shown in Table 3

Table 3 Properties of Sisal fibre

\begin{tabular}{|c|c|}
\hline Properties & Value \\
\hline Diameter $(\mu \mathrm{m})$ & 300 \\
\hline Cut length $(\mathrm{mm})$ & 12 \\
\hline Aspect ratio & 40 \\
\hline
\end{tabular}




\section{Experimentation}

\subsection{Concrete Mix Proportion}

The mixes were choosen in accordance with IS 10262-2009 mix design method. Based on the properties of materials, the mix proportions was arrived for $\mathrm{M}_{25}$ grade concrete. The details of mix proportions and materials required for $1 \mathrm{~m}^{3}$ of concrete was shown in Table 4

Table 4 : Material required for $1 m_{3}$ of Concrete $\left(\mathrm{Kg} / \mathrm{m}_{3}\right)$

\begin{tabular}{|c|c|c|c|c|}
\hline Grade & Cement(kg) & FA(kg) & CA(kg) & Water(lit) \\
\hline $\mathrm{M}_{25}$ & 437.7 & 556.5 & 1080.5 & 197 \\
\hline
\end{tabular}

In this work, percentage of sisal fiber added by weight was $0 \%, 0.05 \%, 0.1 \%, 0.15 \%, 0.20 \%, 0.25 \%, 0.30 \%, 0.35 \%$ and $0.40 \%$, in concrete. Mixes incorporating were designated as CC, S1, S2, S3, S4, S5, S6, S7 and S8 respectively. Quantity of fibers required for $1 \mathrm{~m}^{3}$ of concrete for various mixes are given in Table 5 .

Table 5: Fibre required for $1 m^{3}$ of concrete

\begin{tabular}{|c|c|c|}
\hline \multirow{2}{*}{$\begin{array}{c}\text { Mix } \\
\text { Identification }\end{array}$} & \multicolumn{2}{|c|}{ Sisal Fibre } \\
\cline { 2 - 3 } & in \% & in $\mathbf{~ k g / m 3}$ \\
\hline CC & 0 & 0 \\
\hline S1 & 0.05 & 1.03 \\
\hline S2 & 0.10 & 2.07 \\
\hline S3 & 0.15 & 3.11 \\
\hline S4 & 0.20 & 4.14 \\
\hline S5 & 0.25 & 5.18 \\
\hline S6 & 0.30 & 6.22 \\
\hline S7 & 0.35 & 7.26 \\
\hline S8 & 0.40 & 8.29 \\
\hline
\end{tabular}

\section{Casting of Specimen}

\subsection{Casting of cube specimens for compressive strength:}

The test was conducted as per IS 516-1959. The cubes of standard size $150 \mathrm{X} 150 \mathrm{~mm}$ X $150 \mathrm{~mm}$ were used to find the compressive strength of concrete. Specimens were placed on the Compression Testing machine and uniform rate of loading of 140 $\mathrm{kg} / \mathrm{cm}$ per minute was applied till the failure of the cube.

\subsection{Casting of Beam specimen for structural behaviour evaluation:}

The beam was designed as per IS 456:2000 and the detailing of beam was done by IS 13920:1993. The beam was casted in our laboratory for a dimension of $1300 \mathrm{~mm} \times 115 \mathrm{~mm} \times 180 \mathrm{~mm}$. The shear reinforcement with $8 \mathrm{~mm}$ diameter at spacing of $50 \mathrm{~mm}$ at left and right end over a length of $2 \mathrm{~d}$ and at a spacing of $100 \mathrm{~mm}$ at centre. The 2 numbers of $16 \mathrm{~mm}$ diameter are used in bottom reinforcement and 2 numbers of $12 \mathrm{~mm}$ are used in top reinforcement. The reinforcement detailing of beam is shown in Figure. 2 and Figure. 3 shows the concreting of beam specimen. Addition of optimum percentage of fiber to the beam specimen was determined by the cube compressive strength of the various mixes from S1 to S8.

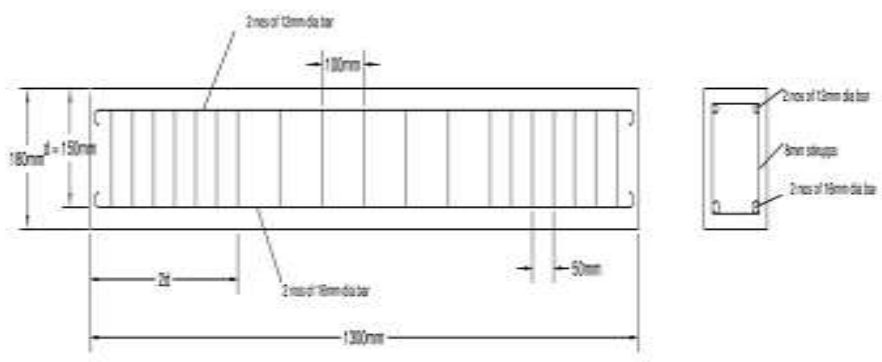

Figure 2 Reinforcement details of Beam 


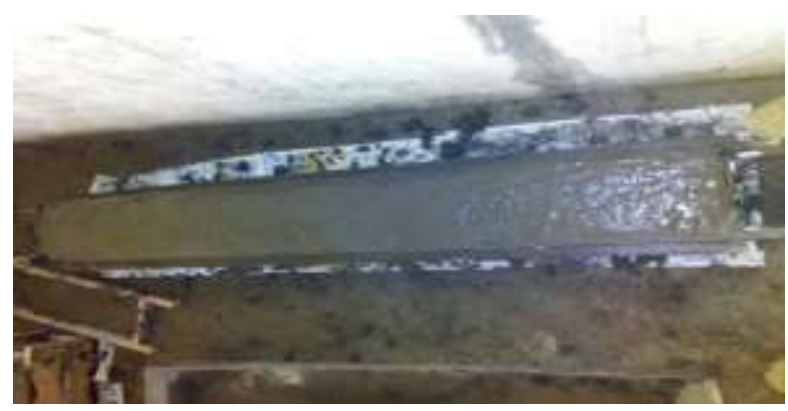

Figure 3 Casting of beam

\section{Testing procedure for specimen}

\subsection{Compressive strength of Sisal Fibre Reinforced Concrete (SFRC)}

The test was conducted as per IS 516-1959. The cubes of standard size 150x150mmx150mm were used to find the compressive strength of concrete. Specimens were placed on the Compression Testing machine and uniform rate of loading of 140 $\mathrm{kg} / \mathrm{cm}$ per minute was applied till the failure of the cube. The maximum load was recorded and the compressive strength value was calculated.

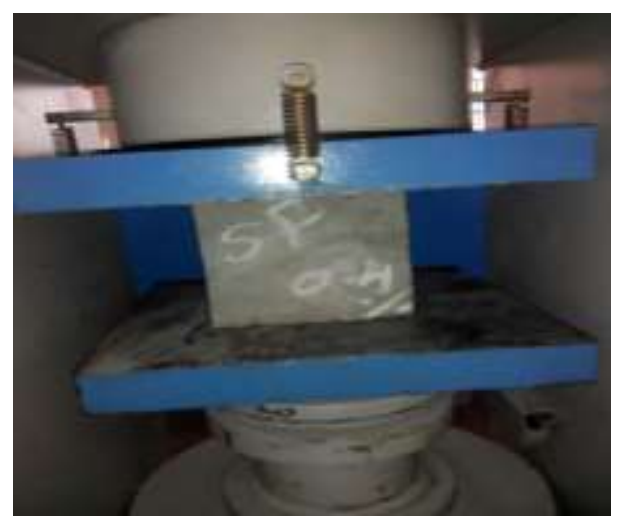

Figure4 Compression Testing for Cube

\subsection{Experimental set up for beam specimen}

The experimental set up for testing of beam specimens is shown in Figure 7. The beam was placed in such a manner that the load applied through the load cell, lever arm in to the two roller support placed in the top of beam. The load was slowly applied to the specimen by using hand operated hydraulic jack. The dial gauge was used to measure the deflection caused at midspan.

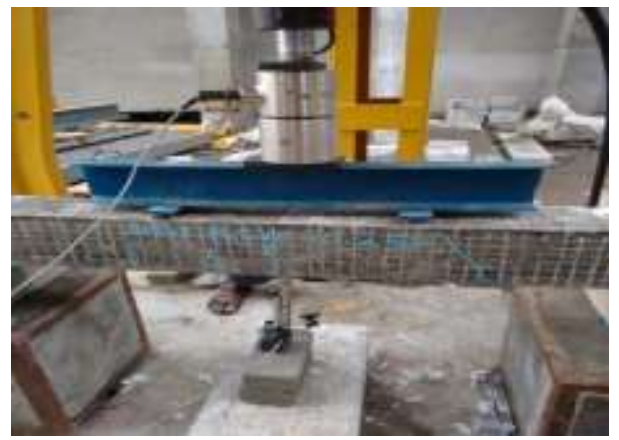

Figure7: Test setup for Beam specimen 


\section{Test Results of Controlled Specimen:}

\subsection{Workability:}

The concrete slump test measures the workability of fresh concrete. This test is performed to check the consistency of freshly made concrete. Consistency is a term very closely related to workability. Compacting factor of fresh concrete is done to determine the workability of fresh concrete by compacting factor test as per IS: $1199-1959$.

The slump and compaction factor value for sisal fibre reinforced concrete shown in Table 5

Table 5 Slump value and Compaction factor value

\begin{tabular}{|c|c|c|c|}
\hline S.no & Identification & $\begin{array}{c}\text { Slump value } \\
(\mathbf{m m})\end{array}$ & $\begin{array}{c}\text { Compaction } \\
\text { factor value }\end{array}$ \\
\hline 1 & CC & 72 & 0.80 \\
\hline 2 & SF1 & 70 & 0.80 \\
\hline 3 & SF2 & 70 & 0.80 \\
\hline 4 & SF3 & 70 & 0.82 \\
\hline 5 & SF4 & 68 & 0.82 \\
\hline 6 & SF5 & 68 & 0.82 \\
\hline 7 & SF6 & 66 & 0.82 \\
\hline 8 & SF7 & 66 & 0.84 \\
\hline 9 & SF8 & 66 & 0.84 \\
\hline
\end{tabular}

\subsection{Compressive strength for SFRC}

The values for compressive strength of concrete for all mixes are shown in Figure 8.The compressive strength of SF1 is $0.6 \%$ increased when initial addition of $0.05 \%$ of sisal fibre by volume of concrete. The results of SF2 is $1.93 \%$ higher than SF1. The next addition of fibre content SF3 specimen is $2.24 \%$ increased compared to SF2 and SF4 is 5.16\% increases than SF3. The compressive strength was increased up to SF5 specimen, it increases $12.34 \%$ than conventional concrete cubes and $0.78 \%$ than the SF4 specimen. From SF6, the strength is slightly decreased from the higher results.

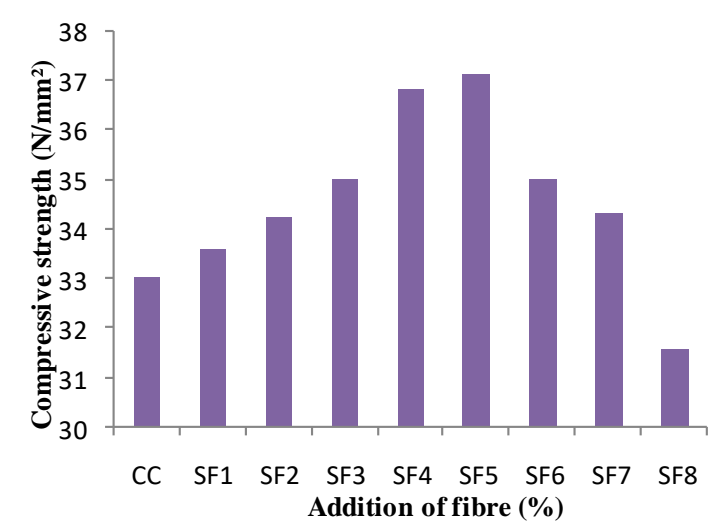

Figure 8 Compressive strength of hardened concrete

\section{Test results of beam}

\subsection{Load carrying capacity and First crack load:}

The first crack load and load carrying capacity of Sisal Fibre Reinforced Concrete(SFRC) beam and Plain Reinforced Concrete Beam specimen(CC) are shown in Figure 9.

The first crack was initiated in $35 \mathrm{kN}$ at the beam for plain Reinforced Concrete Beam specimen (CC) specimen and in $41 \mathrm{kN}$ for SF5. As the load level was increased, cracks were noticed in the sides of the beam specimens. The crack developments were very less compared to the conventional concrete beam. The first load of Control concrete (CC) was slightly higher than that of SF5 specimen. The optimum dosage level of fibre shows increased result compared to the beam without addition of fibre. 


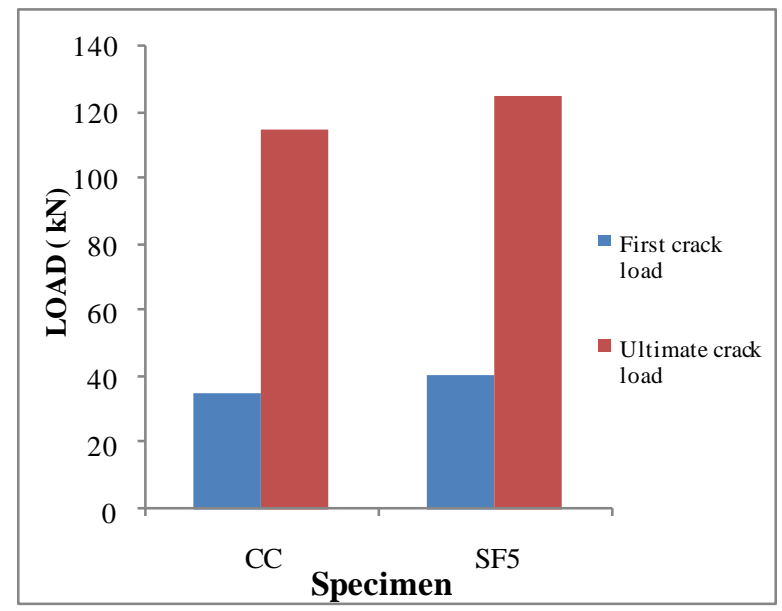

Figure 9 First crack load and ultimate load for CC and SF5 specimen

\subsection{Load deflection curve for RC beam}

The load deflection characteristics for the tested beams are shown in Figure 10 and Figure 11. Load deflection curve shows that behavior of SFRC specimen (SF5) gave better performance compared to plain Reinforced Concrete Beam specimen (CC) mix. Addition of fiber reduces the deflection characteristics of the beam and also increases the Load carrying capacity of the member.

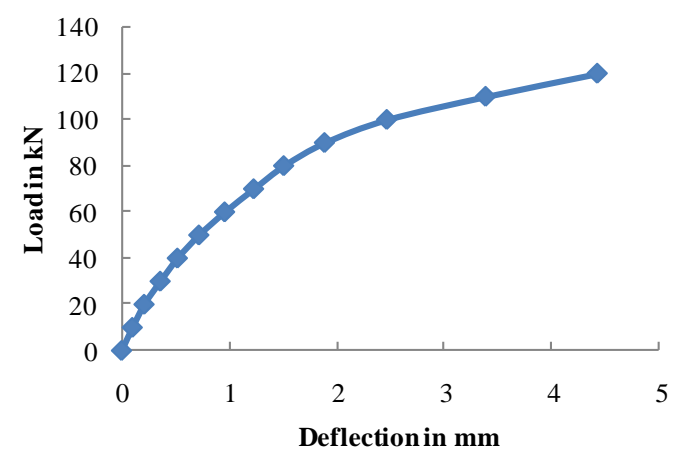

Figure 10 Load Deflection curve for CC Specimen

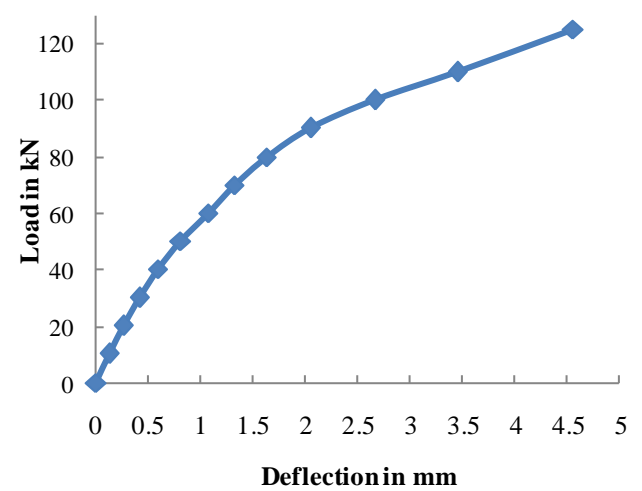

Figure 11 Load Deflection curve for SF5 Specimen

\subsection{Ductility Factor}

The deflection was measured from the load deflection diagram. The ductility of SFRC beam is $4.43 \%$ increased compared to conventional concrete beam. There is no loss of ductility due to addition of fibre by volume of concrete. The ductility factor for all the specimen are shown in Figure 12 


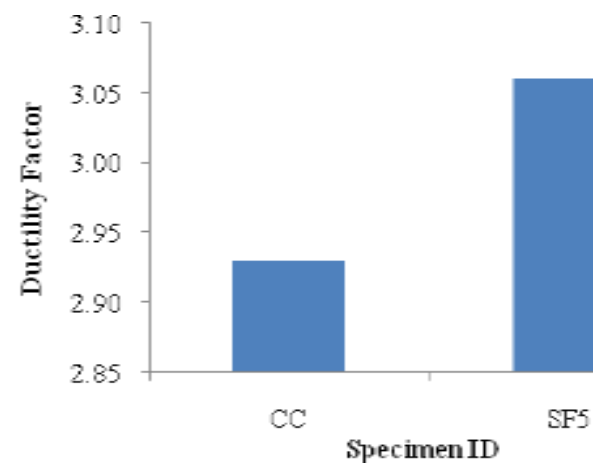

Figure 12 Ductility factor of RC beam

\subsection{Stiffness}

Stiffness is defined as the force applied on the body for a unit displacement. A tangent was drawn from the origin to the load deflection curve and the slope of tangent gives the stiffness values. The stiffness was slightly improved compared to conventional concrete beam.

The stiffness of beam specimen CC and SF5 are shown in Figure 13.

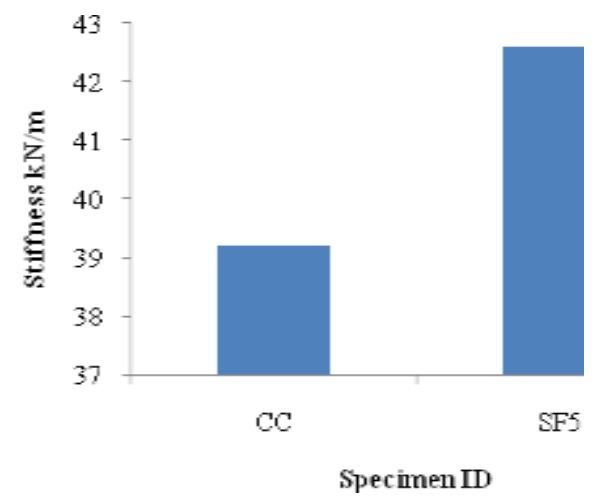

Figure13 Stiffness of Control and SFRC beam

\section{Conclusion}

By this study, the addition of sisl fibre up to $0.25 \%$ in concrete increases the structural behaviour of concrete and its post cracking. The optimum dosage level of addition of Sisal fibre is found as $0.25 \%$ by volume of concrete. The compressive of SFRC is increased by $12.34 \%$ compared to conventional concrete. The load carrying capacity of $0.25 \%$ addition of Sisal fibre in reinforced beams was increased by $5.04 \%$ when compared control concrete beam. The ductility of beam was increased by $4.43 \%$ than that of the control beam when compared to $0.25 \%$ of Sisal fibre in concrete. The stiffness was slightly improved compared to conventional concrete beam. There is a noticeable improvement in behaviour such as first crack load, ultimate crack load, ductility. Due to its performance, it may be used in the structure which is in the earthquake prone areas. 


\section{References}

[1] Di Bella.G, Fiore.V , Galtieri.G, Borsellino.C , Valenza.A, "Effects of natural Fibre reinforcement in lime plasters", Construction and Building Materials 58 (2014) 159-165.

[2] Flávio de Andrade Silva, BarzinMobasher, Romildo Dias Toledo Filho, "Cracking mechanisms in durable sisal fibre reinforced cement composites" Cement \& Concrete Composites 31 (2009) 721-730

[3] Flávio de Andrade Silva, Romildo Dias Toledo Filho,João de Almeida MeloFilho, Eduardo de MoraesRego Fairbairn, "Physical and mechanical properties of durable sisal fibre-cement composites", Construction and Building Materials 24 (2010) 777-785.

[4] IS 12269 : 2013, Indian Standard ordinary portland cement, 53 grade specification( first revision ).

[5] IS 383 - 1970, specification for coarse and fine aggregates from natural sources for concrete( second revision )

[6] IS 9103 : 1999,Indian standard concrete admixtures-specification ( first revision )

[7] Mathur.V.K. "Composite materials from local resources", Construction and Building Materials 20 (2006) 470-477.

[8] Ramesh M, Palanikumar K, Hemachandra Reddy K, "Mechanical property evaluation of sisal-jute-glass fiber reinforced polyester composites", Composites:Part B 48 (2013) 1-9.

[9] Tara Sena, H.N. Jagannatha Reddy, "Flexural strengthening of RC beams using natural sisal and artificialcarbon and glass fabric reinforced composite system",Sustainable Cities and Society 10 (2014) 195-206. 